\title{
Awaiting better times: A quiescence response and adventitious root primordia formation prolong survival under cadmium stress in Tetradenia riparia (Hochst.) Codd
}

\author{
Nadia Bazihizina $^{\mathrm{a}}$, Cosimo Taiti ${ }^{\mathrm{a}}$, Nelson Serre ${ }^{\mathrm{a}}$, Chiara Nocci ${ }^{\mathrm{a}, \mathrm{b}}$, Francesco Spinelli ${ }^{\mathrm{a}}$, \\ Werther Guidi Nissim ${ }^{\mathrm{a}}$, Elisa Azzarello ${ }^{\mathrm{a}}$, Lucia Martia ${ }^{\mathrm{a}}$, Mirvat Redwan ${ }^{\mathrm{a}}$, \\ Cristina Gonnelli ${ }^{\mathrm{b}}$, Stefano Mancuso ${ }^{\mathrm{a}, *}$ \\ a LINV - Department of Agrifood Production and Environmental Sciences - Università degli Studi di Firenze, Viale delle Idee 30,50019 Sesto F.no, Florence, \\ Italy \\ bepartment of Biology, Università degli Studi di Firenze, via Micheli 1, 50121 Florence, Italy
}

\section{A R T I C L E IN F O}

\section{Article history:}

Received 4 February 2016

Received in revised form 28 April 2016

Accepted 7 May 2016

Available online 10 May 2016

\section{Keyword:}

Adventitious roots

Gas exchange

Heavy metals

Histone

Quiescence

Recovery

\begin{abstract}
A B S T R A C T
Plants survive stressful conditions by employing three main strategies: escape, tolerance, and survival. Experiments were conducted to pinpoint the response strategy adopted by Tetradenia riparia to cadmium (Cd) stress by monitoring several physiological parameters and plants' ability to recover once the stress receded. Cadmium ( 30 and $150 \mu \mathrm{M}$ ) strongly affected shoot and root growth in a dose dependent manner, with almost complete inhibition of shoot growth, stomatal opening and $\mathrm{CO}_{2}$ assimilation in plants exposed to $150 \mu \mathrm{M} \mathrm{CdSO}$. Independently of the $\mathrm{CdSO}_{4}$ concentrations, plants excluded $\mathrm{Cd}$ from the aboveground tissues, with concentrations in shoots remaining around $0.1 \mu \mathrm{molg}^{-1}$ dry mass. Furthermore, Cd stress was associated with a decline in methylation of Lys4 of histone H3, likely associated with the transition from an active to a quiescent state. Surprisingly, Cd also induced the initiation of root primordia in $T$. riparia stems, which, once placed in a Cd-free media, quickly (24h) developed into adventitious roots, which were likely the driving factor of the rapid resumption of leaf elongation and photosynthetic activity, which increased almost 20-fold over the 3 weeks of recovery. Therefore $T$. riparia ability to survive Cd stress was mediated by quiescence, which associated with an excluder strategy and stem root primordia formation, enabled rapid resumption of growth under Cd-free conditions.
\end{abstract}

(c) 2016 Elsevier B.V. All rights reserved.

\section{Introduction}

Cadmium (Cd) is a highly toxic trace pollutant for humans, animals and plants, and its presence in the environment has been widely recognized as a serious concern since the 1960s (Pan et al., 2010). Cadmium is naturally present in soils, however recent advances in industry and agriculture stimulate increased deposition of metals in the environment and more than $90 \%$ of $\mathrm{Cd}$ in soils

Abbreviations: $\mathrm{C}_{\mathrm{i}}$, intercellular $\mathrm{CO}_{2}$ concentration; ETR, photosynthetic electron transport rate; $F_{m}$, maximum fluorescence yield; $F_{s}$, steady state fluorescence yield; $\mathrm{F}_{\mathrm{v}} / \mathrm{F}_{\mathrm{m}}$, maximum quantum yield; $\mathrm{g}_{\mathrm{s}}$, stomatal conductance; H3-K4, lysine 4 of histone H3; NPQ non-photochemical quenching; PFDa, absorbed photon flux density; $\mathrm{P}_{\mathrm{n}}$, net photosynthetic rate; PSII, photosystem II; $\Phi_{\mathrm{PSII}}$, actual quantum yield; RWC, relative water content.

* Corresponding author.

E-mail address: stefano.mancuso@unifi.it (S. Mancuso). is currently from anthropogenic sources (Pan et al., 2010). Particularly, high levels can be found when agricultural expedients are used, such as contaminated irrigation water (Caldas and Machado, 2004). It has now been demonstrated that $\mathrm{Cd}$ has cytotoxic, mutagenic and/or carcinogenic effects in animal and has been classified as a human carcinogen (Waalkes, 2003). Given that plants can easily absorb Cd, they are an important source of $\mathrm{Cd}$ exposure for humans through the food chain (Ueno et al., 2009; Lux et al., 2011a,b; Gallego et al., 2012; Uraguchi and Fujiwara, 2012, 2013; Clemens et al., 2013). Therefore intensive researches have been performed to understand the levels of $\mathrm{Cd}$ accumulation in the different plant organs and the effects of this heavy metal on plant physiology (Lux et al., 2011a,b; Clemens et al., 2013; Uraguchi and Fujiwara, 2013). In plants, Cd is a non-essential element and has been found to induce complex changes in plants at genetic, biochemical and physiological levels that ultimately result to substantial growth reductions (Sandalio et al., 2001; Cosio et al., 
2006; Lopez-Millan et al., 2009; Gallego et al., 2012). Cadmium alters a wide array of processes in growing plants, amongst which plant water relations (Haag-Kerwer et al., 1999; Perfus-Barbeoch et al., 2002; Lefevre et al., 2014), leaf gas exchanges (Baryla et al., 2001; Küpper et al., 2007; He et al., 2011; Kieffer et al., 2009; Wang et al., 2009; Parmar et al., 2013), carbohydrate and ion homeostasis (Besson-Bard et al., 2009; Wu et al., 2012; He et al., 2015), and oxidative status (He et al., 2011, 2013a,b).

Plants survive stressful conditions by employing three main strategies: escape (i.e. escaping the stress, e.g., short life cycle limited to the wet season in Mediterranean environments), tolerance and survival. The tolerance strategy involves different mechanisms that enable the plant to tolerate and grow in the presence of the stress (Lawlor, 2013). By contrast, the survival strategy is a form of stress resistance by which cells, tissues, and organs can cease growing in presence of the stress, while maintaining key cellular functions, which enable them to recover rapidly, with minimal damage, once the stress has receded ( $c f$. Lawlor, 2013). This kind of survival has also been termed quiescence, and examples can be found in plants exposed to long periods of drought and salinity (Granot et al., 2009; Julkowska and Testerink, 2015) or in flooded plants (Bailey-Serres and Voesenek, 2008; Colmer et al., 2009; Luo et al., 2011; Bailey-Serres et al., 2012; Sasidharan and Voesenek, 2013). This inherent flexibility of plant in response to a changing environment has been related to the ability of the epigenetic status to alter rapidly and reversibly (Luo et al., 2012). In response to external signals (e.g., stress), plants activate specific signaling pathways that alter physiological reactions and transcription rates of responding genes. Chromatin status, which is governed by pattern and quantity of histone modifications that alter DNA-histone interaction and accessibility of transcription factors, has been implicated in the regulation of eukaryotic gene activity (Chinnusamy and Zhu, 2009; Kim et al., 2008). In particular the primary level controlling gene expression is the structure of chromatin, and modifications of the histone $\mathrm{H} 3$ at lysine 4 (H3-K4) have been associated with the transition from quiescent into active state as they dictate either gene silencing or gene activation (Tsuji et al., 2006; Granot et al., 2009).

Plants have formed the basis of traditional medicine for thousands of years and, while in developing countries a large proportion of the population relies heavily on medicinal plants to meet primary health care needs, increased scientific interest and consumer demand have boosted their use also in developed countries in the past decades (Gurib-Fakim, 2006; Annan et al., 2013; Barthwal et al., 2008). Therefore, in parallel to the increased use of medicinal plants, concerns regarding the safety of their use have risen as they have been recognized as an important source of heavy metal toxicity to both humans and animals and a prolonged consumption of such medicinal plants may be detrimental to health (Dwivedi and Dey, 2002; Haider et al., 2004; Lux et al., 2011a,b). Indeed, despite plants do not require Cd for growth or reproduction, the bioaccumulation index of $\mathrm{Cd}$ in plants exceeds that of all other trace elements (Grant et al., 1998), and, due to its high toxicity, the World Health Organization has set the maximum permissible limit of $\mathrm{Cd}$ in medicinal plants to $0.3 \mu \mathrm{gg}^{-1}$ dry mass (World Health Organization, 1998).

Tetradenia riparia (Hochst.) Codd belongs to the Lamiaceae family and is a widespread aromatic shrub with a height of approximately 1-3 $\mathrm{m}$ occurring throughout eastern and tropical Africa (Gazim et al., 2014). T. riparia occupies a wide range of ecologically contrasting habitats but is often found on hillsides and river banks (Gairola et al., 2009). The family Lamiaceae is rich in aromatic species, which are used as culinary herbs, folk medicines and fragrant scents (Gairola et al., 2009), and in particular T. riparia is a well-known herbal medicine and has traditionally been used in the treatment of various illnesses including coughs, dropsy, fever, and malaria (Gairola et al., 2009; Gazim et al., 2011). Despite being widely used, to date virtually nothing is known about its response to abiotic stress and its potential and safe use in marginal soils (i.e. in areas with a possible pollution of soils by heavy metals) has yet to be evaluated. Henceforth, with the present study we aimed to evaluate the physiological responses of $T$. riparia to the addition of $\mathrm{Cd}$ in the growing media. Therefore, following the observation that T. riparia exhibited the survival strategy response, we tested the following hypotheses: (i) the quiescent response and the prolonged survival of $T$. riparia to $\mathrm{Cd}$ stress is associated with low Cd concentrations in shoot tissues; (ii) the Cd-induced quiescence enables plants to recover rapidly, with minimal damage, once the stress has receded.

\section{Materials and methods}

\subsection{Plant material}

Rooted plants were established from cuttings (3-4 internodes) taken from $T$. riparia plants grown in a naturally lit glasshouse for 1 year in standard potting mix. The cuttings were propagated by inserting them in aerated water for 3-4 weeks in the same glasshouse (with average day/night temperatures during the experimental period of $35 / 25^{\circ} \mathrm{C}$ and an average humidity of $76 \%$ in the two experiments). Rooted cuttings were then transferred to an aerated nutrient solution, which contained: $3 \mathrm{mM} \mathrm{KNO}_{3}, 2 \mathrm{mM}$ $\mathrm{Ca}\left(\mathrm{NO}_{3}\right)_{2}, 1 \mathrm{mM} \mathrm{NH}_{4} \mathrm{H}_{2} \mathrm{PO}_{4}, 0.50 \mathrm{mM} \mathrm{MgSO}_{4}, 40 \mu \mathrm{M} \mathrm{Fe}(\mathrm{Na})$-EDTA, $1 \mu \mathrm{M} \mathrm{KCl}, 25 \mu \mathrm{M} \mathrm{H}_{3} \mathrm{BO}_{3}, 2 \mu \mathrm{M} \mathrm{MnSO}_{4}, 2 \mu \mathrm{M} \mathrm{ZnSO}_{4}, 0.1 \mu \mathrm{M} \mathrm{CuSO}_{4}$, and $0.1 \mu \mathrm{M}\left(\mathrm{NH}_{4}\right)_{6} \mathrm{Mo}_{7} \mathrm{O}_{24}$, and buffered with $1 \mathrm{mM}$ MES. The $\mathrm{pH}$ of the solution was adjusted to 5.8 using $\mathrm{KOH}$. Solutions were changed weekly. Two months after transferring the cuttings to the aerated nutrient solution, plants were selected for shoot and root uniformity, and $\mathrm{CdSO}_{4}$ was added to the nutrient solutions to obtain the required final concentrations.

\subsection{Physiological responses of $\mathrm{T}$. riparia to different concentrations of $\mathrm{CdSO}_{4}$ (Expt 1)}

Experiment 1 (Expt 1) consisted of three treatments with five replicates in a completely randomized block design, where plants were exposed to increasing $\mathrm{Cd}$ concentrations: $0 \mu \mathrm{M} \mathrm{CdSO}$, considered as the control treatment, and 30 and $150 \mu \mathrm{M} \mathrm{CdSO}$. Plants were then harvested 5 weeks after imposing the treatments.

\subsection{Recovery of T. riparia following Cd stress (Expt 2)}

In the second experiment (Expt 2) plants were grown for 5 weeks with a solution containing $150 \mu \mathrm{M} \mathrm{CdSO}_{4}$ and subsequently were transferred in aerated water to assess recovery in the following 3 weeks (i.e., only the root system and the basal portion of the stem bathing in the Cd-free media). In addition, as in the first experiment we observed that Cd strongly induced the formation of root primordia in the top internodes of the stems, cuttings (with all leaves removed except the pair of leaves on the top internode) from the top 3-4 internodes of the stems of control and treated plants were inserted in aerated water to assess leaf and root formation for the following 3 weeks.

\subsection{Leaf and root elongation and leaf sampling (Expt 1 and 2)}

In Expt 1, leaf length was measured every 2-4 days for the duration of the experiment to determine its extension during the treatment period. At different time points (1, 7, 14 and 35 days), young fully expanded leaves (one for each plant in all treatments) were collected between $11.00 \mathrm{~h}$ and $11.30 \mathrm{~h}$ for subsequent analyses of ions, total soluble sugars and leaf pigments. These 
leaf tissues were snap-frozen in liquid $\mathrm{N}_{2}$, stored at $-80^{\circ} \mathrm{C}$, freezedried, and then stored at $-20^{\circ} \mathrm{C}$. In addition, the relative water content (RWC) of the leaves was measured using the following formula RWC $=(F M-D M) /(T M-D M) \times 100$, where FM is leaf fresh mass, DM is leaf dry mass after the leaves were dried at $65^{\circ} \mathrm{C}$ for 3 $\mathrm{d}$, and TM is the turgid mass after leaves were soaked in water for $4 \mathrm{~h}$ at room temperature.

In Expt 2, root number, root and leaf length were measured every 2-4 days for the entire duration of the experiment to determine their extension during the treatment period.

\subsection{Leaf gas exchange parameters (Expt 1 and 2)}

At different time points in both experiments, net photosynthetic rate and stomatal conductance were calculated on young fully expanded leaves in each treatment, using the open gas exchange system Li-6400 (LiCor Inc., Lincoln, NE, USA) as described in Bazihizina et al., 2015. Briefly leaf gas exchange measurements were taken on four plants from each treatment at ambient relative humidity (50-60\%), ambient $\mathrm{CO}_{2}$, flow rate of $400 \mu \mathrm{mol} \mathrm{s}^{-1}$, leaf chamber temperature at $30^{\circ} \mathrm{C}$ and photosynthetically active radiation of $300 \mu \mathrm{mol} \mathrm{m}^{-2} \mathrm{~s}^{-1}$.

In Expt 1, using the integrated fluorescence chamber head ( $\mathrm{Li}$ 6400-40; Li-Cor Inc.) of the open gas exchange system Li-6400 (LiCor Inc., Lincoln, NE, USA) chlorophyll fluorescence was measured on the same leaves used for gas exchange measurements. Maximum quantum yield $\left(\mathrm{F}_{\mathrm{v}} / \mathrm{F}_{\mathrm{m}}\right)$ was determined after a 30 min dark acclimation of selected leaves using a dark leaf clip. Actual quantum yield $\left(\Phi_{\mathrm{PSII}}\right)$ was measured on light adaptedleaves and was calculated as $\Phi_{\mathrm{PSII}}=\left(\mathrm{F}_{\mathrm{m}^{\prime}}-\mathrm{F}_{\mathrm{s}}\right) / \mathrm{F}_{\mathrm{m}^{\prime}}$, which measures the proportion of the light absorbed by chlorophyll associated with PSII that is used in photochemistry (Maxwell and Johnson 2000). Fluorescence parameters were also used to calculate the nonphotochemical quenching $\left(\mathrm{NPQ}=\left(\mathrm{F}_{\mathrm{m}}-\mathrm{F}_{\mathrm{m}^{\prime}}\right) / \mathrm{F}_{\mathrm{m}^{\prime}}\right.$; Redondo-Gomez et al., 2006), which is linearly related to heat dissipation (Maxwell and Johnson 2000). ETR was calculated as ETR $=\Phi_{\text {PSII }} \times$ PFDa $\times 0.5$, where PFDa is absorbed light in $\mu \mathrm{mol}$ photon $\mathrm{m}^{-2} \mathrm{~s}^{-1}$ and 0.5 is a factor that accounts for the partitioning of energy between PSII and PSI (Maxwell and Johnson 2000).

\subsection{Plant harvest (Expt 1)}

In Expt 1, plants were sampled at the beginning of the experiment and 5 weeks after applying the treatments for the determination of shoot and root fresh and dry mass. Roots were carefully washed three times and each plant was separated into roots, leaves and stems and their fresh mass was recorded. Tissue samples were then oven-dried at $60^{\circ} \mathrm{C}$ for 1 week to determine their dry mass.

\subsection{Leaf pigment analyses (Expt 1)}

Cold $100 \%$ methanol was added to $10-20 \mathrm{mg}$ of the ground freeze-dried tissues and the samples were incubated in darkness, on ice. After $30 \mathrm{~min}$, samples were centrifuged at $9300 \mathrm{~g}$ for $10 \mathrm{~min}$ at $4{ }^{\circ} \mathrm{C}$, the supernatants were removed and their absorbance was determined at 470, 665.2 and $652.4 \mathrm{~nm}$, using a Tecan Infinite 200 Spectrophotometer (Männedorf, Switzerland). Total chlorophyll and carotenoid concentrations were calculated using the equations from Wellburn (1994).

\subsection{Determination of $K$ and $C d$ concentrations in plants (Expt 1 )}

Potassium concentrations in dry plant tissues were obtained after digesting of ground tissues in $0.5 \mathrm{M} \mathrm{HNO}_{3}$ by shaking vials for $48 \mathrm{~h}$ in dark at $25^{\circ} \mathrm{C}$. Diluted extracts were analysed for $\mathrm{K}$ concentrations (Digiflame DV710, NT Laboratory). Cd concentrations in dry plant tissues were obtained following a digestion in a mixture of concentrated $\mathrm{HNO}_{3}$ and $\mathrm{HClO}_{4}$ (2:1 v.v., Sigma-Aldrich, Italy) using a digester (VELP Scientifica, Italy). Cd concentrations were then determined with an inductively coupled plasma-optical emission spectrometer (ICP-OES, OPTIMA 2000 DV, PerkinElmer, USA). The ICP analytical standard (AA/ICP calibration/check standards for environmental analyses, $1 \mathrm{~g} \mathrm{~L}^{-1}$ ) for $\mathrm{Cd}$ was supplied by Sigma-Aldrich.

\subsection{Acid extraction of proteins and immunoblotting (Expt 1)}

Leaves of 5 weeks treated plants of $T$. riparia were ground using a T25 Ultra-Turrax (Ika Labortechnik) in an extraction buffer (100 mM Tris- $\mathrm{HCl}$ pH 7,5, 2 mM EDTA 5 mM 2-Mercaptoethanol $2 \mathrm{mM}$ Phenylmethylsulfonyl fluoride, $\mathrm{HCl} 0.25 \mathrm{M}$ ) supplemented with a protease inhibitor cocktail (Sigma-Aldrich St. Louis, MO product number P9599). The acid soluble proteins were TCAAceton precipitated and protein concentration estimated with the Bradford Assay (Bio-Rad Hercules CA product number 500-0006). Acid soluble proteins $(20 \mu \mathrm{g})$ were separated in 15\% SDS-PAGE and stained with Comassie brilliant blue $\mathrm{R}$ (Merck Darmstadt) or blotted on nitrocellulose paper (Bio-rad Hercules CA product number 162-0115). The following two different antibodies were probed to evaluated the dimethylation of H3: abH3 (Sigma-Aldrich St. Louis, MO product number H0164) for immunodetection of total histon3 fraction and anti-dimethylated H3K4 (Sigma-Aldrich St. Louis, MO product number D5692). Immunodetection was performed using secondary antibody of goat anti-rabbit horseradish peroxidase conjugate (Sigma-Aldrich St. Louis, MO product number A0545). To strip the nitrocellulose a stripping buffer composed by $62.5 \mathrm{mM}$ Tris- $\mathrm{HCl}$ pH 6.7, $100 \mathrm{mM}$ 2-Mercaptoethanol $2 \%$ SDS was used, and after the stripping, the nitrocellulose paper was incubated with secondary antibody of goat anti-rabbit horseradish peroxidase conjugate to evaluate background signal.

\subsection{Statistical analyses}

Statistical analyses were conducted using GraphPad for Mac 6th Edition, and analysis of variance (ANOVA) was used to identify overall significant differences between treatments. Tukey post-hoc test was used for a posteriori comparison of individual means (with at least $P<0.05$ as significant level).

\section{Results}

\subsection{Plant growth (Expt 1)}

Increasing concentration of $\mathrm{Cd}$ in the nutrient solutions reduced plant growth, with substantial declines in plant dry mass increments and leaf elongation (Table 1 and Fig. 1). For example, with $150 \mu \mathrm{M} \mathrm{CdSO}_{4}$ there was no net dry mass increment for both shoots and roots. The used $\mathrm{Cd}$ concentrations resulted toxic for root

\section{Table 1}

Net dry mass increments in Tetradenia riparia in response to different concentration of $\mathrm{CdSO}_{4}$ in the culture media (Expt 1). Values are mean \pm S.E. $(n=5)$. Different lower case letters in each column indicate significant differences between control and treated plants. Initial leaf, stem and root dry mass were respectively $(\mathrm{g})$ : $7.1 \pm 0.6 ; 20.5 \pm 3.1 ; 4.8 \pm 0.4$.

\begin{tabular}{llcr}
\hline $\mathrm{CdSO}_{4}$ treatment & \multicolumn{3}{l}{ Net dry mass increment $\left(\mathrm{g} \mathrm{plant}^{-1}\right)$} \\
\cline { 2 - 4 } & \multicolumn{1}{l}{ Leaves } & Stems & Roots \\
\hline 0 & $26.8 \pm 3.3 \mathrm{a}$ & $21.1 \pm 7.2 \mathrm{a}$ & $13.4 \pm 4.2 \mathrm{a}$ \\
30 & $5.3 \pm 0.5 \mathrm{~b}$ & $3.0 \pm 2.2 \mathrm{~b}$ & $3.0 \pm 0.8 \mathrm{~b}$ \\
150 & $2.3 \pm 0.5 \mathrm{c}$ & $1.6 \pm 1.6 \mathrm{~b}$ & $0.0 \pm 0.9 \mathrm{~b}$ \\
\hline
\end{tabular}



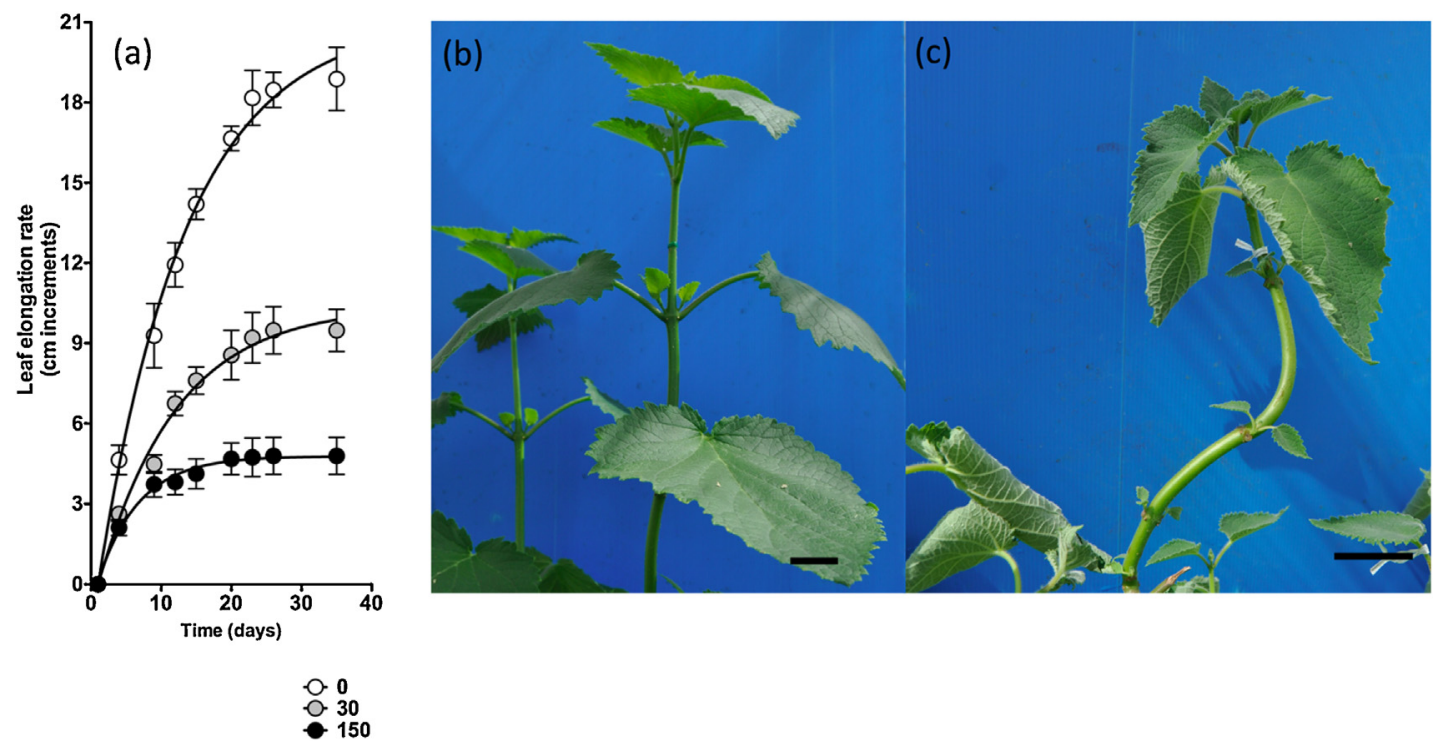

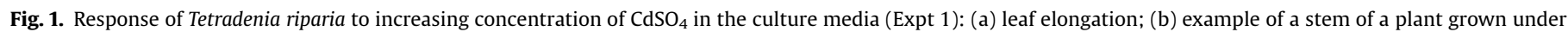
control conditions (scale bar, $5 \mathrm{~cm}$ ); (c) example of a stem of a plant exposed to $150 \mu \mathrm{M}$ CdSO4 for 5 weeks $(\mathrm{scale}$ bar, $5 \mathrm{~cm}$ ). In $(\mathrm{a})$ values are mean \pm S.E. ( $\mathrm{n}=5$ ).

growth (Table 1), and with $150 \mu \mathrm{M} \mathrm{CdSO}$ the entire plant root system was completely necrotic (Fig. S1). As for plant dry mass, leaf elongation was strongly inhibited in time (more than $60 \%$ declines in both Cd treatments, Table S1) by the stress in all Cd treatments, although the reductions were accentuated with $150 \mu \mathrm{M} \mathrm{CdSO}$ (Fig. 1a). Cadmium immediately affected plant water relations, and one day after applying the treatments, independently from the $\mathrm{Cd}$ concentrations, relative water content (RWC) of the youngest expanded leaves declined to almost 50\% compared to that in control plants (Fig. S2a). However, with time, in plants treated with $30 \mu \mathrm{M} \mathrm{CdSO}_{4}$, RWC recovered to values similar to those of control plants, meanwhile in plants exposed to $150 \mu \mathrm{M} \mathrm{CdSO} \mathrm{CWC}_{4} \mathrm{RW}$ was most times lower than that in control plants.

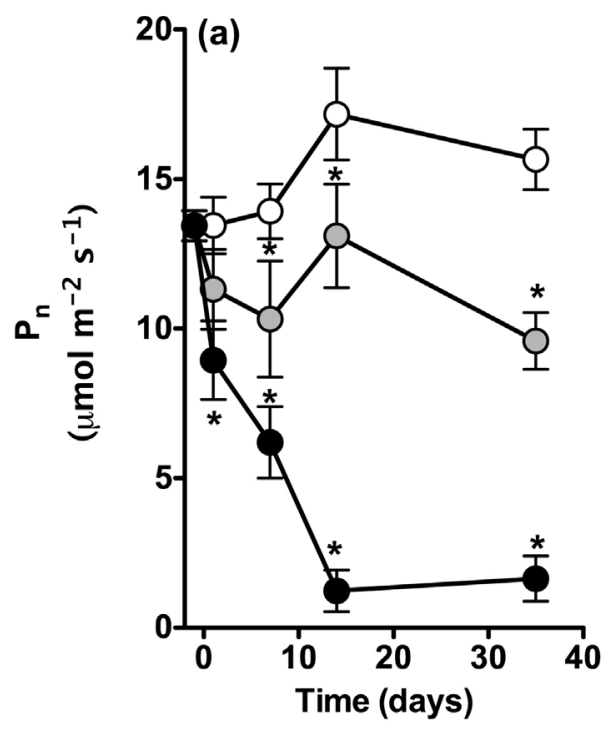

\subsection{Gas exchange and chlorophyll fluorescence (Expt 1)}

In all times considered, net $\mathrm{CO}_{2}$ assimilation and stomatal conductance were reduced by $\mathrm{Cd}$ treatments (Fig. 2). One day after the treatments stomatal conductance decreased by 60 and $80 \%$ in plants exposed to 30 and $150 \mu \mathrm{M} \mathrm{CdSO}_{4}$, respectively, and in both cases values never returned to those measured in control plants. Leaf photosynthetic activity had a similar trend to the one observed for stomatal conductance.

Chlorophyll fluorescence results showed that the maximum quantum efficiency of PSII was not affected by Cd treatments throughout the entire experimental period (Table 2, Fig. S3). However, although after one day of treatment, for all Cd concentrations considered there were no significant changes in
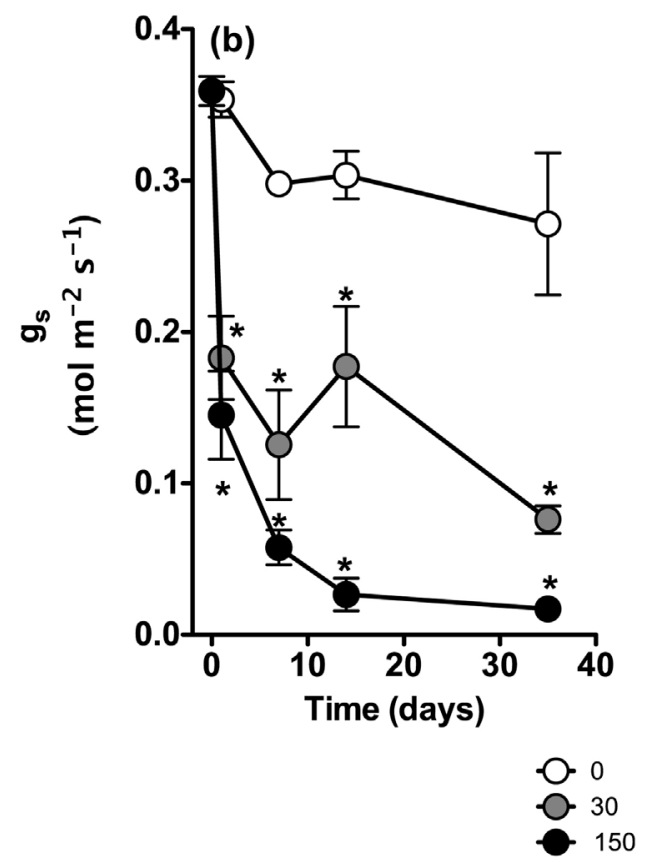

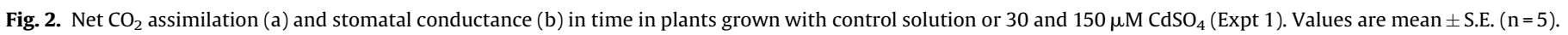
Asterisks indicate significant differences between control and $C d$ treated plants. ${ }^{*} P<0.05 ;{ }^{* *} P<0.01 ;{ }^{* * *} P<0.001$. 
Table 2

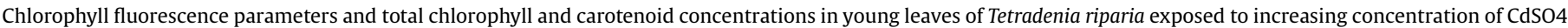

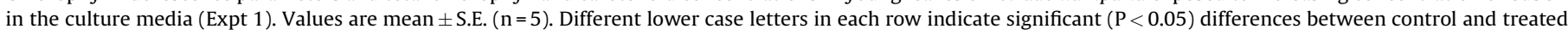

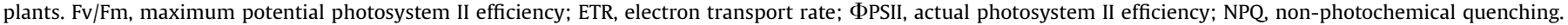

\begin{tabular}{|c|c|c|c|}
\hline \multirow[t]{2}{*}{ Parameter } & \multicolumn{2}{|c|}{$\mathrm{CdSO}_{4}$ treatment $(\mu \mathrm{M})$} & \multirow[b]{2}{*}{150} \\
\hline & 0 & 30 & \\
\hline $\mathrm{F}_{\mathrm{v}} / \mathrm{F}_{\mathrm{m}}$ & $0.93 \pm 0.00 a$ & $0.91 \pm 0.02 \mathrm{a}$ & $0.90 \pm 0.02 a$ \\
\hline $\operatorname{ETR}\left(\mu \mathrm{mol} \mathrm{e}{ }^{-} \mathrm{m}^{-2} \mathrm{~s}^{-1}\right)$ & $93.48 \pm 3.74 a$ & $75.13 \pm 4.33 b$ & $35.59 \pm 8.79 c$ \\
\hline$\Phi_{\text {PSII }}$ & $0.18 \pm 0.01 \mathrm{a}$ & $0.14 \pm 0.01 b$ & $0.11 \pm 0.01 \mathrm{c}$ \\
\hline NPQ & $1.59 \pm 0.04 a$ & $2.04 \pm 0.20 b$ & $3.16 \pm 0.36 c$ \\
\hline Total chlorophyll ( $\mu \mathrm{g} \mathrm{mg}^{-1}$ dry mass) & $8.51 \pm 0.62 \mathrm{a}$ & $8.68 \pm 0.57 a$ & $6.10 \pm 0.51 b$ \\
\hline Carotenoid ( $\mu \mathrm{g} \mathrm{mg}^{-1}$ dry mass) & $1.52 \pm 0.10 a$ & $1.71 \pm 0.11 \mathrm{a}$ & $0.96 \pm 0.07 b$ \\
\hline
\end{tabular}

Table 3

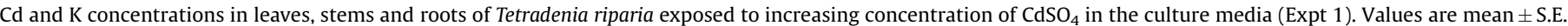
$(n=5)$. Different lower case letters in each row indicate significant differences between control and treated plants. nd, not detectable.

\begin{tabular}{|c|c|c|c|c|c|c|c|c|c|}
\hline \multirow[t]{3}{*}{ Parameter } & \multicolumn{9}{|c|}{$\mathrm{CdSO}_{4}$ treatment $(\mu \mathrm{M})$} \\
\hline & \multicolumn{3}{|l|}{ Leaves } & \multicolumn{3}{|l|}{ Stems } & \multicolumn{3}{|l|}{ Roots } \\
\hline & 0 & 30 & 150 & 0 & 30 & 150 & 0 & 30 & 150 \\
\hline $\mathrm{Cd}\left(\mu \mathrm{molg}^{-1}\right.$ dry mass $)$ & nd & $0.03 \pm 0.01 a$ & $0.07 \pm 0.01 \mathrm{c}$ & nd & $0.06 \pm 0.01 \mathrm{a}$ & $0.12 \pm 0.01 b$ & nd & $8.55 \pm 2.62 \mathrm{a}$ & $23.94 \pm 3.47 b$ \\
\hline $\mathrm{K}\left(\mu \mathrm{molg}^{-1}\right.$ dry mass $)$ & $1120 \pm 25 a$ & $1177 \pm 35 a$ & $994 \pm 71 a$ & $1093 \pm 132 a$ & $1009 \pm 99 a, b$ & $902 \pm 38 b$ & $854 \pm 32 a$ & $498 \pm 53 b$ & $533 \pm 76 b$ \\
\hline
\end{tabular}

all measured chlorophyll fluorescence parameters, in time there was a progressive decline in the actual quantum yield of PSII and in the electron transport rate, associated with a progressive increase in the non-photochemical quenching (Fig. S3). For example, with $150 \mu \mathrm{M} \mathrm{CdSO}_{4}$, at the end of the 5 weeks of treatments, Cd stress resulted in a $60 \%$ and $40 \%$ declines in ETR and $\Phi_{\text {PSII }}$, respectively, and a 2-fold increase in NPQ compared with control plants (Table 2).

\subsection{Total chlorophyll and carotenoid concentrations in youngest expanded leaves (Expt 1)}

For the first 14 days after treatment, for all Cd concentrations considered there were no significant declines in both total chlorophyll and carotenoid concentrations in the youngest expanded leaves (Fig. S4). However, 5 weeks of treatment with $150 \mathrm{MM} \mathrm{CdSO}_{4}$ resulted in 27-37\% declines in total chlorophyll and carotenoid concentrations. By contrast, $30 \mu \mathrm{M} \mathrm{CdSO}_{4}$ did not affect the concentration of these two leaf photosynthetic pigments (Table 2).

\subsection{Cd and $K$ concentrations (Expt 1)}

In all Cd treatments, $\mathrm{Cd}$ accumulation was limited in stems and especially in leaves in comparison to roots (Table 3 ). Independently from the $\mathrm{Cd}$ concentration in the culture media, $\mathrm{Cd}$ concentrations in both leaves and stems remained within or close $0.1 \mu \mathrm{mol} \mathrm{Cd} \mathrm{g}{ }^{-1}$ dry mass. At the end of the experiment, for both Cd treatments, root $K$ concentration decreased as compared with control plants. In both leaves and stems, $\mathrm{K}$ concentrations did not vary between (a)

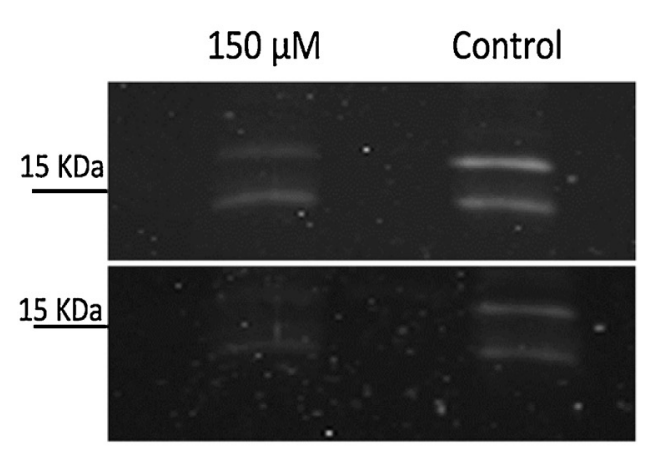

(b)

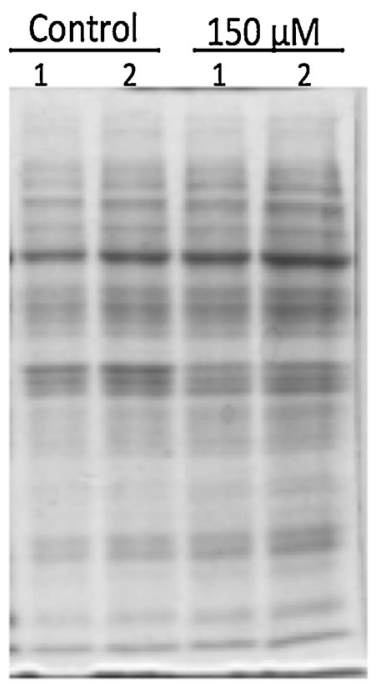

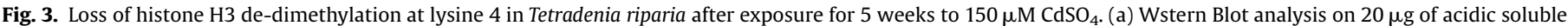

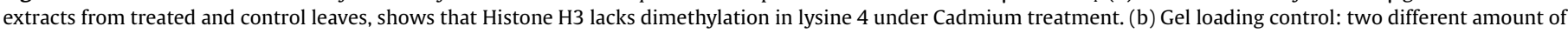
protein $(10$ and $20 \mu \mathrm{g}$ ) were loaded in the gel and then stained with Coomassie brilliant blue. 
Table 4

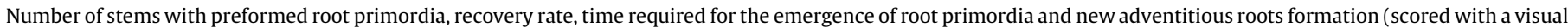

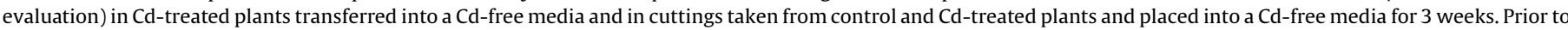

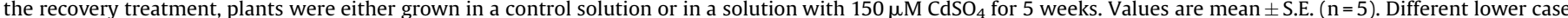

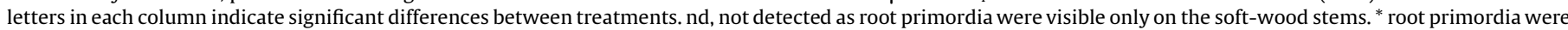
already visible prior to the recovery treatment.

\begin{tabular}{|c|c|c|c|c|c|}
\hline & & $\begin{array}{l}\text { Stems with visible root primordia } \\
(\%)\end{array}$ & $\begin{array}{l}\text { Recovery rate } \\
(\%)\end{array}$ & $\begin{array}{l}\text { Root primordia visible (days from } \\
\text { recovery) }\end{array}$ & $\begin{array}{l}\text { Emergence new roots (days from } \\
\text { recovery) }\end{array}$ \\
\hline Control plants & Cuttings & $9 \pm 6 a$ & 100 & $6.5 \pm 0.2 \mathrm{a}$ & $9.7 \pm 0.4 \mathrm{a}$ \\
\hline \multirow[t]{2}{*}{$\begin{array}{l}\text { Cd-treated } \\
\text { plants }\end{array}$} & $\begin{array}{l}\text { Entire } \\
\text { plants }\end{array}$ & nd & 80 & $5.0 \pm 1.7 a$ & $10.2 \pm 3.6 a$ \\
\hline & Cuttings & $88 \pm 10 b$ & 100 & $0 b^{*}$ & $1.2 \pm 0.2 \mathrm{~b}$ \\
\hline
\end{tabular}

control plants and plants treated with $30 \mu \mathrm{M} \mathrm{CdSO}_{4}$ (Table 3), whereas at $150 \mu \mathrm{M} \mathrm{CdSO}$, leaf and stem $\mathrm{K}$ concentrations decreased by approximately $10-15 \%$ as compared with concentrations in control plants.

\subsection{Histone post translational modifications following Cd stress (Expt 1)}

The dynamics of histone modifications after 5 weeks of $\mathrm{CdSO}_{4}$ treatments were analyzed, focusing on the demethylation of lysine 4 , as this modification has previously been associated in plants with decondensed, transcriptionally active chromatin (Pfluger and Wagner 2007; Granot et al., 2009). Compared with the control plants, exposure for 5 weeks to $150 \mu \mathrm{M} \mathrm{CdSO}_{4}$ led to the loss of the demethylation in lysine 4 (Fig. 3 ) meanwhile this drastic change did not occur in plants treated with $30 \mu \mathrm{M} \mathrm{CdSO}_{4}$ (Fig. S5). Moreover, we loaded on the SDS-PAGE 10 and $20 \mu \mathrm{g}$ of acidic extracts and then performed a Comassie Brillant Blue staining (Fig. 3b), in order to confirm the estimation of proteins through Bradford Assay.
3.6. Growth recovery and adventitious root formation following $\mathrm{Cd}$ stress (Expt 2)

Cd stress strongly induced the initiation of root primordia on the stem of treated plants, resulting in the formation, after 2-3 weeks of treatment, of several primordia, mostly in the first few internodes of the stems of Cd-treated plants (Table 4 and Fig. 4). Therefore, once cuttings taken from these top internodes from Cdtreated plants were transferred in a Cd-free media, these new root primordia quickly developed into adventitious roots, despite their activation and development in adventitious roots was strictly local, and primordia that remained dry never got activated. Indeed, in Cd-treated cuttings, adventitious root growth occurred very quickly, with visible roots already after $24 \mathrm{~h}$ of recovery treatment meanwhile in control plants root primordia initiation and subsequent adventitious root formation occurred on average only after 6-10 days (Table 4 and Figs. 4 and 5).

In the recovery experiment, most plants previously exposed to Cd (80\% of all plants in the recovery experiment and $100 \%$ of all plants for the cutting experiment, see Table 4) were able to form

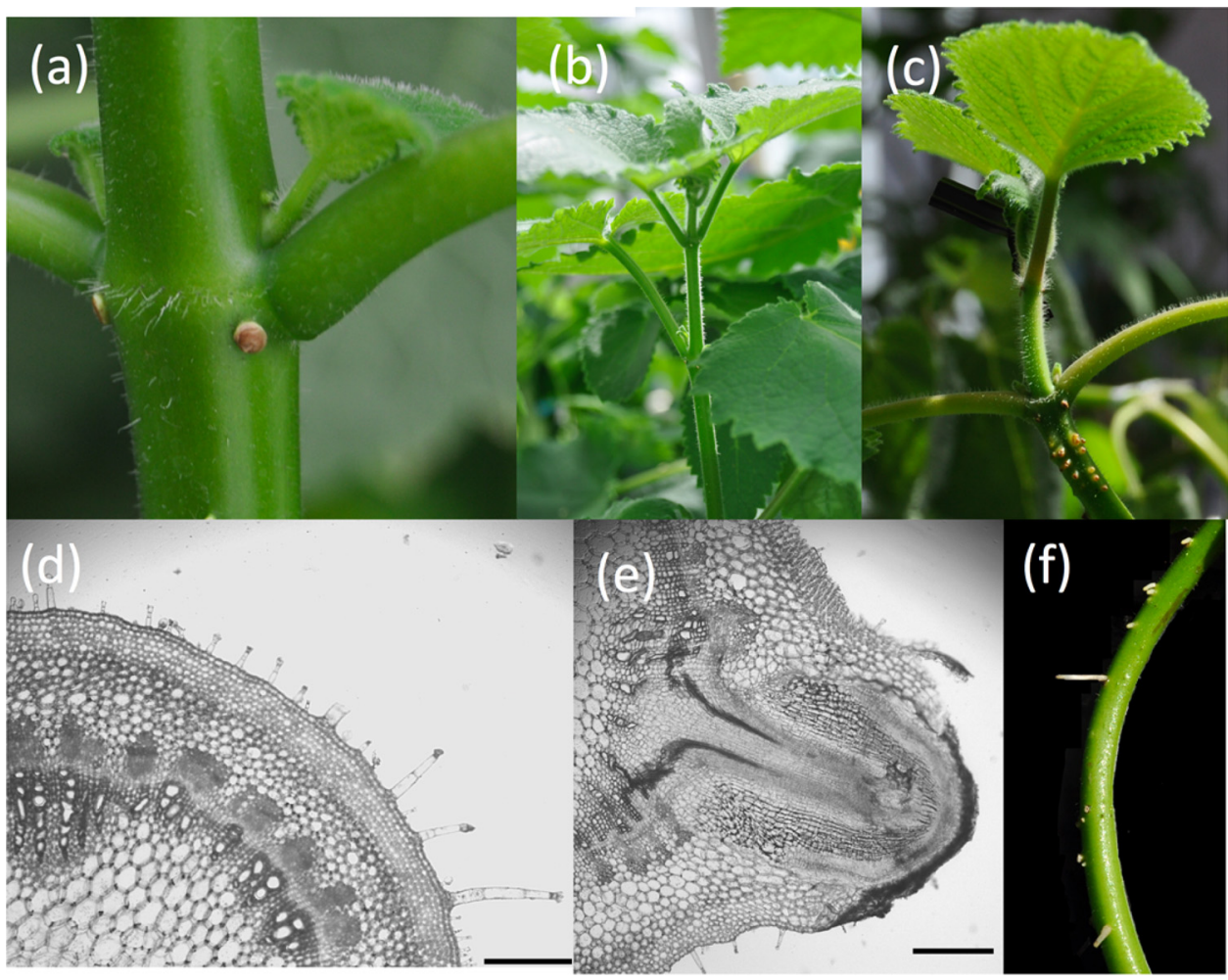

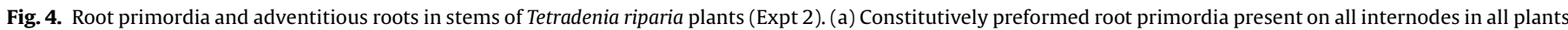

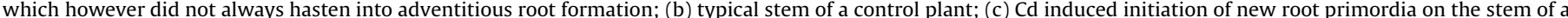

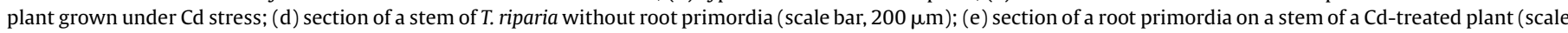
bar, $200 \mu \mathrm{m}$ ); (f) the $\mathrm{Cd}$-induced root primordia developed in $24-48 \mathrm{~h}$ into adventitious roots when in a Cd-free media. 

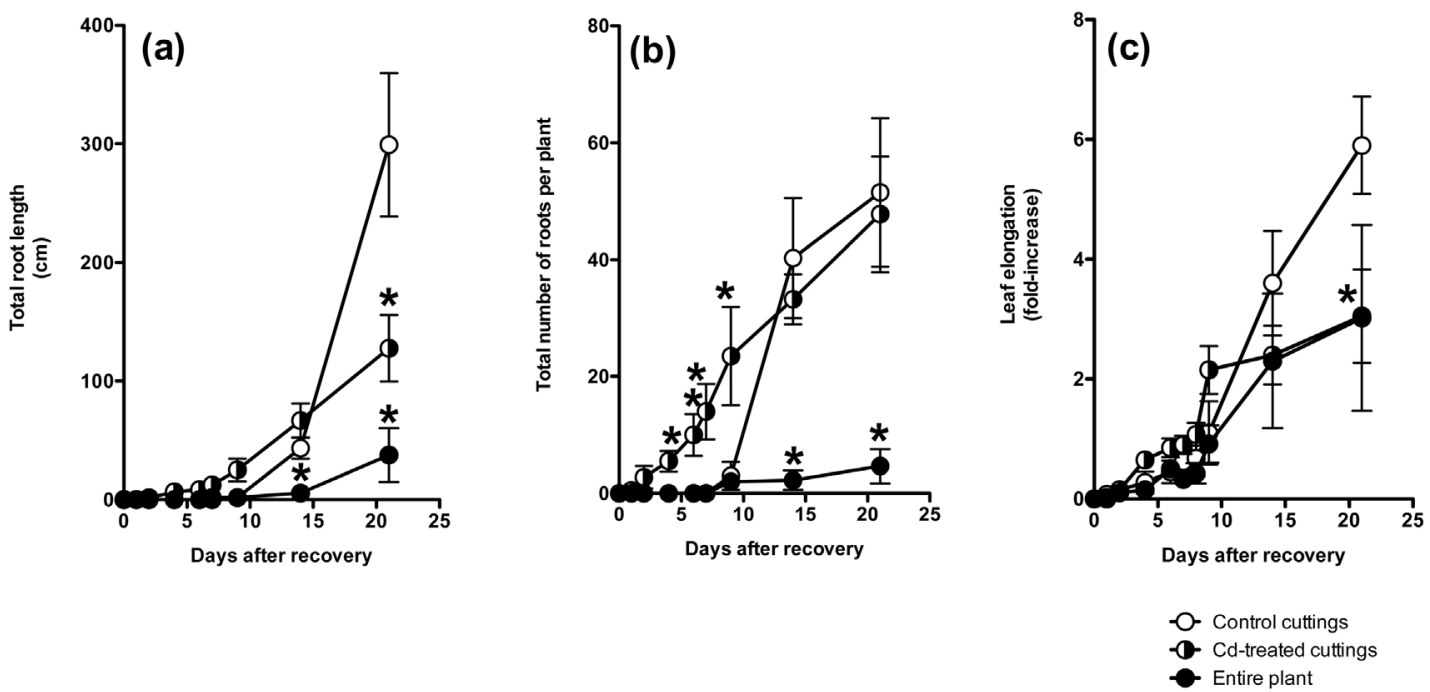

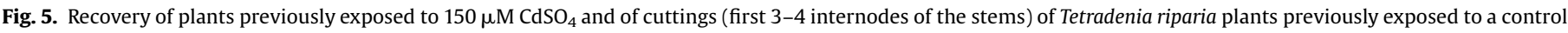

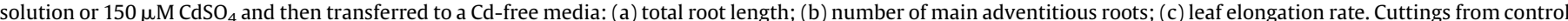

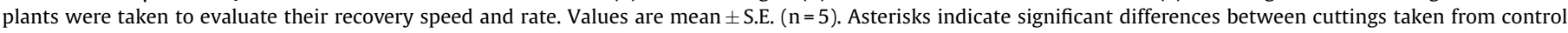
plants and cuttings taken from $C d$ treated plants. ${ }^{*} P<0.05$.

new roots and leaves once placed in a Cd-free media, as shown by the progressive increase in leaf elongation, leaf photosynthetic activity and stomatal conductance (Figs. 5 and 6, Table S2). In particular, when cuttings were taken from plants previously treated with $150 \mu \mathrm{M} \mathrm{CdSO}_{4}$, leaf photosynthetic activity increased from an average value of 0.3 to an average value of $5.6 \mu \mathrm{M} \mathrm{CO}_{2}$ $\mathrm{m}^{-2} \mathrm{~s}^{-1}$ during the 3-week recovery period (Fig. 6a). Despite the observed increases in leaf elongation and photosynthetic activity in cuttings previously treated with $\mathrm{Cd}, 3$ weeks after the recovery treatment, leaf and root lengths of cuttings from control plants were approximately double than those of cuttings from treated plants (Fig. 5). When considering the recovery of the entire plants (i.e., with only the root system and the basal portion of the stem bathing in the Cd-free media), recovery was significantly slower, as the initiation of root primordial in Cd-treated plants occurred mainly in the first few internodes of the stems, and adventitious root formation was seen on average only 10 days after the recovery treatment (Table 4, Fig. 5).
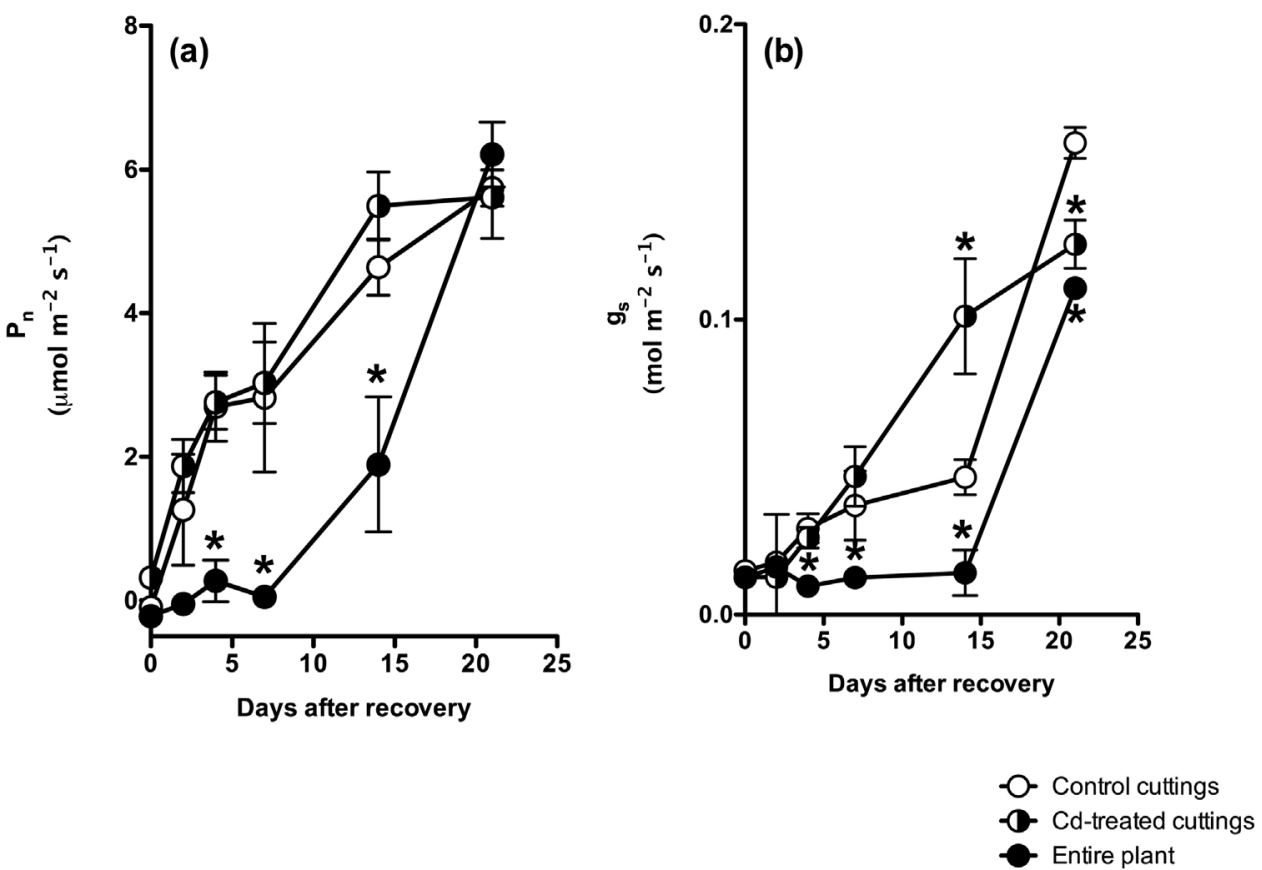

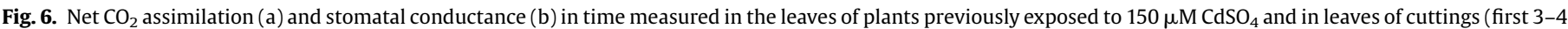

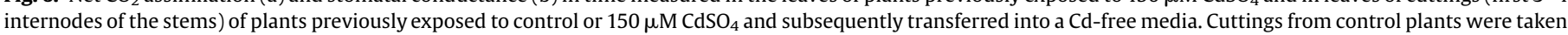

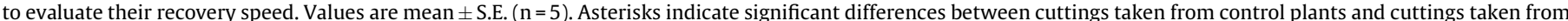

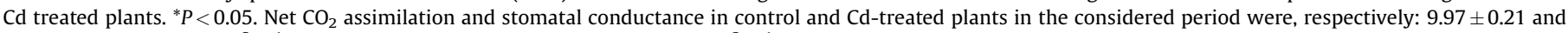
$-0.33 \pm 0.11\left(\mu \mathrm{M} \mathrm{CO}_{2} \mathrm{~m}^{-2} \mathrm{~s}^{-1}\right) ; 0.336 \pm 0.003$ and $0.004 \pm 0.000\left(\mathrm{~mol} \mathrm{H}_{2} \mathrm{O} \mathrm{m}^{-2} \mathrm{~s}^{-1}\right)$. 


\section{Discussion}

The quiescence strategy has been considered pivotal in prolonging plant survival under stressful conditions and to improve survival rate and generation of new tissues after the stress has receded (Greenway and Gibbs 2003; Fukao and BaileySerres, 2004; Bailey-Serres and Voesenek, 2008; Colmer et al., 2009; Luo et al., 2011). We observed that, following Cd stress, $T$. riparia adopted a quiescence-like response and there was an enhanced formation of adventitious root primordia in the stems. We therefore subsequently tested and confirmed the following hypotheses: (i) the quiescent response and the prolonged survival of $T$. riparia to Cd stress is associated with low Cd concentrations in shoot tissues; (ii) the Cd-induced quiescence enables plants to recover rapidly, with minimal damage, once the stress has receded; and (iii) root primordia will quickly develop into adventitious roots in more favourable conditions, therefore enabling the plants to rapidly exploit new environmental opportunities.

Cadmium affected $T$. riparia growth in a dose dependent manner, and $150 \mu \mathrm{M} \mathrm{CdSO}_{4}$ quickly arrested leaf elongation rates and resulted in widespread necrosis and eventually death of the entire root system after 5 weeks of treatment (Fig. S1). This strong reduction in the root growth, and subsequent root death, with $150 \mu \mathrm{M} \mathrm{CdSO}_{4}$ could be directly linked with the large accumulation of $\mathrm{Cd}$ in root tissues, as already observed for other species (e.g., Perfus-Barbeoch et al., 2002). Cadmium concentrations were found to be several folds higher in roots than in shoots, with concentrations up to $241 \mu \mathrm{molg}^{-1}$ dry mass. By contrast, Cd concentrations in shoots remained within or close to $0.1 \mu \mathrm{mol} \mathrm{g}{ }^{-1}$ dry mass, a clear indication of restricted accumulation of $\mathrm{Cd}$ in shoots. However, with both 30 and $150 \mu \mathrm{M} \mathrm{CdSO}$, Cd concentrations in leaves and stems exceeded by far the limit for maximum $\mathrm{Cd}$ levels for medicinal plants $\left(0.3 \mu \mathrm{g} \mathrm{g}^{-1}\right.$ dry mass, i.e. $0.003 \mu \mathrm{mol}$ $\mathrm{g}^{-1}$ dry mass), indicating that this species is not suitable as a medicinal plant when cultivated in substrates with even moderate Cd concentrations. Nevertheless, this exclusion of Cd from the above-ground tissues was sufficient to avoid the irreversible damage of these tissues, and shoots of treated plant remained alive, as clearly shown by the fast resumption of photosynthesis and leaf elongation once the stress receded.

Cadmium stress quickly affected shoot water relations, as shown by the substantial declines in leaf relative water content and stomatal conductance in the first $24 \mathrm{~h}$ of treatments. Indeed, as declines in leaf photosynthetic rate were paralleled by declines in stomatal conductance and $\mathrm{C}_{\mathrm{i}}$ (Fig. S2b), these results support the view that photosynthesis was initially limited by $\mathrm{CO}_{2}$ diffusion as a consequence of low leaf stomatal conductance ( Medrano et al., 2002). This result is in accordance with the increasing evidence suggesting that exposure to toxic metal concentrations initially affects plant water relations (Barcelo and Poschenrieder, 1990; Sagardoy et al., 2010; Bazihizina et al., 2014). For instance, in Arabidopsis thaliana, exposure to $50-100 \mu \mathrm{M} \mathrm{Cd}$ resulted in a progressive decline in leaf stomatal conductance, with a complete stomatal closure 4-6 days after the treatments (Perfus-Barbeoch et al., 2002). Several factors could explain these initial declines in stomatal opening following Cd stress. Cadmium has been found to cause strong depolarization of root cortical cells, down to values within the range of the diffusion potential (Sanz et al., 2009). This altered root membrane functionality could explain the rapid declines in stomatal conductance as it is now well established that changes at the root level can quickly, through rapid systemic long-distance signals, regulate stomatal behaviour (Comstock 2002; Christmann et al., 2007; Choi et al., 2014). In alternative, it has been suggested that $\mathrm{Cd}$ can enter the guard cells through calcium channels thus affecting guard cell regulation and stomatal opening (Perfus-Barbeoch et al., 2002). However, given the observed responses in $T$. riparia, this second hypothesis seems less likely as $\mathrm{Cd}$ concentrations measured in shoots was low, even after 5 weeks of treatments. Nevertheless, from the seventh day on, prolonged $\mathrm{Cd}$ stress led substantial declines in the actual efficiency of PSII and ETR and increases in non-photochemical quenching, which coincided with great reductions in $\mathrm{CO}_{2}$ assimilation rates. This would indicate that, although initially decreased photosynthesis was associated with declines in stomatal conductance, subsequently Cd impaired leaf photosynthetic machinery. Indeed, although the type of damage varies based on the species used and the environmental contingencies (e.g., Krupa et al., 1993; Küpper et al., 2007), photosynthetic reactions belong to the most important sites affected by Cd, with PSII often identified as one of the main target (Küpper et al., 2007).

The hypothesis that $\mathrm{Cd}$ induced a quiescent-like response in T. riparia was further confirmed by the histone $\mathrm{H} 3$ posttranslational modifications, which resulted in the loss of the methylation of Lys4 of histone H3 (H3-K4) after Cd stress. Indeed, histone modifications, such as methylation and acetylation, in the chromatin surrounding genes are thought to regulate transcriptional activity and gene expression, with the methylation of H3-K4 generally associated with transcriptionally active chromatin (Pfluger and Wagner 2007; Granot et al., 2009). As plants are sessile organisms it has been shown that gene expression is dynamically controlled in response to the appearance or disappearance of an environmental stress through reversible and dynamic changes in histone modification (Tsuji et al., 2006), and declines in dimethylation of H3-K4 have been linked with the entry of the plants into a quiescent state during stressful periods (Granot et al., 2009).

Adventitious roots develop ectopically from aboveground organs and form naturally from stem tissue and/or under stressful environmental conditions (e.g. flooding, drought or salt stress, Wang et al., 2009; Liao et al., 2012; Steffens and Rasmussen, 2016) to replace the existing root system that has either been killed or whose function is impaired by the stress (Pezeshki 2001; Dawood et al., 2014). In particular, despite being phytotoxic, heavy metal stress has been found to induce specific 'stress-induced morphogenic responses' (cf. Potters, 2007; Xu et al., 2011), including the enhanced formation of adventitious roots (Gad and Atta-Aly, 2006). In agreement with these findings, our data show that high Cd stress leads to characteristic stress-induced morphogenic responses: a reduction in primary root growth and, at $150 \mu \mathrm{M} \mathrm{CdSO}$, a concomitant induction of root primordia formation in most stems (Fig. 4). As reported for Solanum dulcamara under flooded conditions (Dawood et al., 2014), root primordia activation and development into adventitious roots was local, as primordia that remained dry never developed into a root (data not shown). These Cd-induced root primordia enabled a much faster resumption of plant growth (root and leaf elongation and leaf photosynthetic activity) compared with control cuttings and treated plants that had only the primordia-free portion of the stem exposed to the Cd-free, where de novo initiation of root primordia was required (Table 4 ). This result can be explained by considering that in cuttings previously treated with $\mathrm{Cd}$, during the first week of recovery, leaf photosynthetic activity was correlated with root elongation rather than leaf growth (Table S3). It would therefore be reasonable to expect that carbohydrate retained or newly synthesized in leaves after recovery were initially used for a quick adventitious root growth. Subsequently, from the second week of recovery, there was a change in the trend, and leaf photosynthetic activity was correlated mainly with the relative leaf elongation, which would suggest a shift in photoassimilate partitioning. 


\section{Conclusion}

Based on the remarkable survival capacity of $T$. riparia under Cd stress and the growth resumption under optimal conditions, we bring forward the hypothesis that this species adopted the quiescence strategy in response to $\mathrm{Cd}$ stress. Indeed the response of $T$. riparia to Cd stress was associated with: (a) a 'quiescence response', i.e., no biomass accumulation, associated with histone H3 modification; (b) a limited Cd accumulation in shoot tissues; and (c) the induction of root primordia. What might be the physiological and ecological significance of the observed responses in T. riparia in a Cd-rich environment? It has been suggested that both quiescence and stress induced morphogenic responses in general are a mechanism for stress evasion (Potters, 2007). Given that $T$. riparia is not a metallophyte, and by definition adaptive responses to $\mathrm{Cd}$ could not have evolved under natural selection, the response described in the present study are likely to represent an inherent general purpose response of $T$. riparia to transient adverse growth conditions, which enables plants to quickly resume normal growth in more favourable conditions, increasing plants' ability to rapidly exploit new environmental opportunities.

\section{Funding}

This research was supported by funding from the Italian Defence Ministry (research project: "VESPA-VEgetal System for Pollution Avoidance").

\section{Acknowledgement}

We thank the Shangrila association for providing the plant material.

\section{Appendix A. Supplementary data}

Supplementary data associated with this article can be found, in the online version, at http://dx.doi.org/10.1016/j. envexpbot.2016.05.006.

\section{References}

Annan, K., Dickson, R.A., Amponsah, I.K., Nooni, I.K., 2013. The heavy metal contents of some selected medicinal plants sampled from different geographical locations. Pharmacogn. Res. 5, 103-108.

Bailey-Serres, J., Voesenek, L.A.C.J., 2008. Flooding stress: acclimations and genetic diversity. Annu. Rev. Plant Biol. 59, 313-339.

Bailey-Serres, J., Lee, S.C., Brinton, E., 2012. Waterproofing crops: effective flooding survival strategies. Plant Physiol. 160, 1698-1709.

Barcelo, J., Poschenrieder, C., 1990. Plant water relations as affected by heavy-metal stress-a review. J. Plant Nutr. 13, 1-37.

Barthwal, J., Nair, S., Kakkar, P., 2008. Heavy metal accumulation in medicinal plants collected from environmentally different sites. Biomed. Environ. Sci. 21, 319324.

Baryla, A., Carrier, P., Franck, F., Coulomb, C., Sahut, C., Havaux, M., 2001. Leaf chlorosis in oilseed rape plants (Brassica napus) grown on cadmium-polluted soil: causes and consequences for photosynthesis and growth. Planta 212, 696709.

Bazihizina, N., Taiti, C., Marti, L., Rodrigo-Moreno, A., Spinelli, F., Giordano, C., et al., 2014. $\mathrm{Zn}^{2+}$-induced changes at the root level account for the increased tolerance of acclimated tobacco plants. J. Exp. Bot. 65, 4931-4942.

Bazihizina, N., Colzi, I., Giorni, E., Mancuso, S., Gonnelli, C., 2015. Photosynthesizing on metal excess: copper differently induced changes in various photosynthetic parameters in copper tolerant and sensitive Silene paradoxa L. populations. Plant Sci. 232, 67-76.

Besson-Bard, A., Gravot, A., Richaud, P., Auroy, P., Duc, C., Gaymard, F., et al., 2009. Nitric oxide contributes to cadmium toxicity in Arabidopsis by promoting cadmium accumulation in roots and by up-regulating genes related to iron uptake. Plant Physiol. 149, 1302-1315.

Caldas, E.D., Machado, L.L., 2004. Cadmium: mercury and lead in medicinal herbs in Brazil. Food Chem. Toxicol. 42, 599-603.

Chinnusamy, V., Zhu, J.K., 2009. Epigenetic regulation of stress responses in plants. Curr. Opin. Plant Biol. 12, 133-139.
Choi, W.G., Toyota, M., Kim, S.H., Hilleary, R., Gilroy, S., 2014. Salt stress-induced Ca ${ }^{2+}$ waves are associated with rapid: long-distance root-to-shoot signaling in plants. Proc. Natl Acad. Sci. U. S. A. 111, 6497-6502.

Christmann, A., Weiler, E.W., Steudle, E., Grill, E., 2007. A hydraulic signal in root-toshoot signalling of water shortage. Plant J. 52, 167-174.

Clemens, S., Aarts, M.G.M., Thomine, S., Verbruggen, N., 2013. Plant science: the key to preventing slow cadmium poisoning. Trends Plant Sci. 18, 92-99.

Colmer, T.D., Vos, H., Pedersen, O., 2009. Tolerance of combined submergence and salinity in the halophytic stem-succulent Tecticornia pergranulata. Ann. Bot.103, 303-312.

Comstock, J.P., 2002. Hydraulic and chemical signalling in the control of stomatal conductance and transpiration. J. Exp. Bot. 53, 195-200.

Cosio, C., Vollenweider, P., Keller, C., 2006. Localization and effects of cadmium in leaves of a cadmium-tolerant willow (Salix viminalis L:) I. Macrolocalization and phytotoxic effects of cadmium. Environ. Exp. Bot. 58, 64-74.

Dawood, T., Rieu, I., Wolters-Arts, M., Derksen, E.B., Mariani, C., Visser, E.J.W., 2014. Rapid flooding-induced adventitious root development from preformed primordia in Solanum dulcamara. AoB Plants doi:http://dx.doi.org/10.1093/ aobpla/plt058.

Dwivedi, S.K., Dey, S., 2002. Medicinal herbs: a potential source of toxic metal exposure for man and animals in India. Arch. Environ. Health 57, 229-231.

Fukao, T., Bailey-Serres, J., 2004. Plant responses to hypoxia-is survival a balancing act? Trends Plant Sci. 9, 449-456.

Gad, N., Atta-Aly, M.A., 2006. Effect of cobalt on the formation: growth and development of adventitious roots in tomato and cucumber cuttings. J App Sci Res. 2, 423-429.

Gairola, S., Naidoo, Y., Bhatt, A., Nicholas, A., 2009. An investigation of the foliar trichomes of Tetradenia riparia (Hochst.) Codd Lamiaceae: an important medicinal plant of Southern Africa. Flora 204, 325-330.

Gallego, S.M., Pena, L.B., Barcia, R.A., Azpilicueta, C.E., Lannone, M.F., Rosales, E.P., et al., 2012. Unravelling cadmium toxicity and tolerance in plants: insight into regulatory mechanisms. Environ. Exp. Bot. 83, 33-46.

Gazim, Z.C., Demarchi, I.G., Lonardoni, M.V.C., Amorim, A.C.L., Hovell, A.M.C. Rezende, C.M., Ferreira, G.A., Lima, E.L., Cosmo, F.A., Cortez, D.A.G., 2011. Acaricidal activity of the essential oil from Tetradenia riparia (Lamiaceae) on the cattle tick Rhipicephalus (Boophilus) microplus (Acari, Ixodidae). Exp. Parasitol. 129, 175-178.

Gazim, Z.C., Rodrigues, F., Lourenco Amorin, A.C., de Rezende, C.M., Sokovic, M., Tesevic, V., et al., 2014. New natural diterpene-type abietane from tetradenia riparia essential oil with cytotoxic and antioxidant activities. Molecules 19, 514524.

Granot, G., Sikron-Persi, N., Gaspan, O., Florentin, A., Talwara, S., Paul, L.K., et al., 2009. Histone modifications associated with drought tolerance in the desert plant Zygophyllum dumosum Boiss. Planta 231, 27-34.

Grant, C.A., Buckley, W.T., Bailey, L.D., Selles, F., 1998. Cadmium accumulation in crops. Can. J. Plant Sci. 78, 1-17.

Greenway, H., Gibbs, J., 2003. Mechanisms of anoxia tolerance in plants. II. Energy requirements for maintenance and energy distribution to essential processes. Funct. Plant Biol. 30, 999-1036.

Gurib-Fakim, A., 2006. Medicinal plants: traditions of yesterday and drugs of tomorrow. Mol. Aspects Med. 27, 1-93.

Haag-Kerwer, A., Schafer, H.J., Heiss, S., Walter, C., Rausch, T., 1999. Cadmium exposure in Brassica juncea causes a decline in transpiration rate and leaf expansion without effect on photosynthesis. J. Exp. Bot. 50, 1827-1835.

Haider, S., Naithani, V., Barthwal, J., Kakkar, P., 2004. Heavy metal content in some therapeutically important medicinal plants. Bull. Environ. Contam. Toxicol. 72, 119-127.

He, J.L., Qin, J.J., Long, L.Y., Ma, Y.L., Li, H., Li, K., Jiang, X.N., Liu, T.X., Polle, A., Liang, Z. S., Luo, Z.B., 2011. Net cadmium flux and accumulation reveal tissue-specific oxidative stress and detoxification in Populus x canescens. Physiol. Plant 143, 50-63.

He, J.L., Li, H., Luo, J., Ma, C.F., Li, S.J., Qu, L., Gai, Y., Jiang, X.N., Janz, D., Polle, A., Tyree, M., Luo, Z.B., 2013a. A transcriptomic network underlies microstructural and physiological responses to cadmium in Populus x canescens. Plant Physiol. 162, 424-439.

He, J.L., Ma, C.F., Ma, Y.L., Li, H., Kang, J.Q., Liu, T.X., Polle, A., Peng, C.H., Luo, Z.B., 2013b. Cadmium tolerance in six poplar species. Environ. Sci. Pollut. Res. 20, 163-174.

He, J., Li, H., Ma, C., Zhang, Y., Polle, A., Rennenberg, H., Cheng, X., Luo, Z.-B., 2015. Overexpression of bacterial <gamma>-glutamylcysteine synthetase mediates changes in cadmium influx allocation, and detoxification in poplar. New Phytol. 205, 240-254.

Julkowska, M.M., Testerink, C., 2015. Tuning plant signaling and growth to survive salt. Trends Plant Sci. 20, 586-594.

Küpper, H., Parameswaran, A., Leitenmaier, B., Trtilek, M., Setlik, I., 2007. Cadmiuminduced inhibition of photosynthesis and long-term acclimation to cadmium stress in the hyperaccumulator Thlaspi caerulescens. New Phytol. 175, 655-674.

Kieffer, P., Planchon, S., Oufir, M., Ziebel, J., Dommes, J., Hoffmann, L., et al., 2009. Combining proteomics and metabolite analyses to unravel cadmium stressresponse in poplar leaves. J. Proteome Res. 8, 400-417.

Kim, J.M., To, T.K., Ishida, J., Morosawa, T., Kawashima, M., Matsui, A., et al., 2008. Alterations of lysine modifications on the histone H3 N-tail under drought stress conditions in Arabidopsis thaliana. Plant Cell Physiol. 49, 1580-1588.

Krupa, Z., Öquist, G., Huner, N.P.A., 1993. The effects of cadmium on photosynthesis of Phaseolus vulgaris-a fluorescence analysis. Physiol. Plant 88, 626-630. 
Lawlor, D.W., 2013. Genetic engineering to improve plant performance under drought: physiological evaluation of achievements, limitations, and possibilities. J. Exp. Bot. 64, 83-108.

Lefevre, I., Vogel-Mikus, K., Jeromel, L., Vavpetic, P., Planchon, S., Arcon, I., et al., 2014. Differential cadmium and zinc distribution in relation to their physiological impact in the leaves of the accumulating Zygophyllum fabago L. Plant Cell Environ. 37, 1299-1320.

Liao, W.B., Huang, G.B., Yu, J.H., Zhang, M.L., 2012. Nitric oxide and hydrogen peroxide alleviate drought stress in marigold explants and promote its adventitious root development. Plant Physiol. Biochem. 58, 6-15.

Lopez-Millan, A.F., Sagardoy, R., Solanas, M., Abadia, A., Abadia, J., 2009. Cadmium toxicity in tomato (Lycopersicon esculentum) plants grown in hydroponics. Environ. Exp. Bot. 65, 376-385.

Luo, F.L., Nagel, K.A., Scharr, H., Zeng, B., Schurr, U., Matsubara, S., 2011. Recovery dynamics of growth: photosynthesis and carbohydrate accumulation after desubmergence: a comparison between two wetland plants showing escape and quiescence strategies. Ann. Bot. 107, 49-63.

Luo, M., Liu, X., Singh, P., Cui, Y., Zimmerli, L., Wu, K., 2012. Chromatin modifications and remodeling in plant abiotic stress responses. Biochim. Biophys. Acta 1819, 129-136.

Lux, A., Martinka, M., Vaculik, M., White, P.J., 2011a. Root responses to cadmium in the rhizosphere: a review. J. Exp. Bot. 62, 21-37.

Lux, A., Vaculik, M., Martinka, M., Liskova, D., Kulkarni, M.G., Stirk, W.A., Van Staden, J., 2011b. Cadmium induces hypodermal periderm formation in the roots of the monocotyledonous medicinal plant Merwilla plumbea. Ann. Bot. 107, 285-292.

Maxwell, K., Johnson, G.N., 2000. Chlorophyll fluorescence-a practical guide. J. Exp. Bot. 51, 659-668.

Medrano, H., Escalona, J.M., Bota, J., Gulìas, J., Flexas, J., 2002. Regulation of photoshyntesis of C3 plants in response to progressive drought: stomatal conductance as a reference parameter. Ann. Bot. 89 (7), 895-905.

Pan, J., Plant, J.A., Voulvoulis, N., Oates, C.J., Ihlenfeld, C., 2010. Cadmium levels in Europe: implications for human health. Environ. Geochem. Health 32, $1-12$.

Parmar, P., Kumari, N., Sharma, V., 2013. Structural and functional alterations in photosynthetic apparatus of plants under cadmium stress. Bot. Stud. 54, 4551.

Perfus-Barbeoch, L., Leonhardt, N., Vavasseur, A., Forestier, C., 2002. Heavy metal toxicity: cadmium permeates through calcium channels and disturbs the plant water status. Plant J. 32, 539-548.

Pezeshki, S.R., 2001. Wetland plant responses to soil flooding. Environ. Exp. Bot. 46 299-312.

Pfluger, J., Wagner, D., 2007. Histone modifications and dynamic regulation of genome accessibility in plants. Curr. Opin. Plant Biol. 10, 645-652.

Potters, G., 2007. Stress-induced morphogenic responses: growing out of trouble? Trends Plant Sci. 12, 98-105.
Redondo-Gomez, S., Wharmby, C., Castillo, J.M., Mateos-Naranjo, E., Luque, C.J., de Cires, A., et al., 2006. Growth and photosynthetic responses to salinity in an extreme halophyte Sarcocornia fruticosa. Physiol. Plant. 128, 116-124.

Sagardoy, R., Vazquez, S., Florez-Sarasa, I., Albacete, A., Ribas-Carbo, M., Flexas, J., et al., 2010. Stomatal and mesophyll conductances to $\mathrm{CO}_{2}$ are the main limitations to photosynthesis in sugar beet (Beta vulgaris) plants grown with excess zinc. New Phytol. 187, 145-158.

Sandalio, L.M., Dalurzo, H.C., Gomez, M., Romero-Puertas, M.C., del Rio, L.A., 2001 Cadmium-induced changes in the growth and oxidative metabolism of pea plants. J. Exp. Bot. 52, 2115-2126.

Sanz, A., Llamas, A., Ullrich, C.I., 2009. Distinctive phytotoxic effects of Cd and Ni on membrane functionality. Plant Signal. Behav. 4, 980-982.

Sasidharan, R., Voesenek, L.A.C.J., 2013. Lowland rice: high-end submergence tolerance. New Phytol. 197, 1029-1031.

Steffens, B., Rasmussen, A., 2016. The physiology of advantageous adventitious roots. Plant Physiol. 170, 603-617.

Tsuji, H., Saika, H., Tsutsumi, N., Hirai, A., Nakazono, M., 2006. Dynamic and reversible changes in histone $\mathrm{H} 3$-Lys4 methylation and $\mathrm{H} 3$ acetylation occurring at submergence-inducible genes in rice. Plant Cell Physiol. 47, 9951003.

Ueno, D., Kono, I., Yokosho, K., Ando, T., Yano, M., Ma, J.F., 2009. A major quantitative trait locus controlling cadmium translocation in rice (Oryza sativa). New Phytol. 182, 644-653.

Uraguchi, S., Fujiwara, T., 2012. Cadmium transport and tolerance in rice: perspectives for reducing grain cadmium accumulation. Rice 5. doi:http://dx. doi.org/10.1186/1939-8433-5-5.

Uraguchi, S., Fujiwara, T., 2013. Rice breaks ground for cadmium-free cereals. Curr. Opin. Plant Biol. 16, 328-334.

Waalkes, M.P., 2003. Cadmium carcinogenesis. Mutat. Res. Fund. Mol. M 533, 107120.

Wang, Y., Li, K., Li, X., 2009. Auxin redistribution modulates plastic development of root system architecture under salt stress in Arabidopsis thaliana. J. Plant Physiol. $166,1637-1645$.

Wellburn, A.R., 1994. The spectral determination of chlorophyll a and chlorophyll b, as well as total carotenoids, using various solvents with spectrophotometers of different resolution. J. Plant Physiol. 144, 307-313.

World Health Organization. (1998). Quality control methods for medicinal plant materials. Geneva, Switzerland.

Wu, H.L., Chen, C.L., Du, J., Liu, H., Cui, Y., Zhang, Y., et al., 2012. Co-overexpression FIT with AtbHLH38 or AtbHLH39 in Arabidopsis-enhanced cadmium tolerance via increased cadmium sequestration in roots and improved iron homeostasis of shoots. Plant Physiol. 158, 790-800.

Xu, S., Zhang, B., Cao, Z.Y., Ling, T.F., Shen, W.B., 2011. Heme oxygenase is involved in cobalt chloride-induced lateral root development in tomato. Biometals 24,181 191. 